\title{
Prospects of Back Surface Field Effect in Ultra-Thin High-Efficiency CdS/CdTe Solar Cells from Numerical Modeling
}

\author{
Nowshad Amin, ${ }^{1,2,3}$ M. A. Matin, ${ }^{1,4}$ M. M. Aliyu, ${ }^{1}$ M. A. Alghoul, ${ }^{2}$ \\ M. R. Karim, ${ }^{3}$ and K. Sopian ${ }^{2}$ \\ ${ }^{1}$ Department of Electrical, Electronics and System Engineering, Faculty of Engineering and Built Environment, \\ The National University of Malaysia (UKM), 43600 Bangi, Selangor, Malaysia \\ ${ }^{2}$ Solar Energy Research Institute, Universiti Kebangsaan Malaysia (UKM), Bangi, Selangor 43600, Malaysia \\ ${ }^{3}$ Center of Excellence for Research in Engineering Materials (CEREM), College of Engineering, King Saud University, \\ Riyadh 11421, Saudi Arabia \\ ${ }^{4}$ Department of Electrical \& Electronics Engineering, Chittagong University of Engineering and Technology (CUET), \\ Chittagong 4348, Bangladesh
}

Correspondence should be addressed to Nowshad Amin, nowshad@eng.ukm.my and M. A. Matin, imamatin@yahoo.com

Received 31 August 2010; Accepted 18 November 2010

Academic Editor: Fahrettin Yakuphanoglu

Copyright (C) 2010 Nowshad Amin et al. This is an open access article distributed under the Creative Commons Attribution License, which permits unrestricted use, distribution, and reproduction in any medium, provided the original work is properly cited.

Polycrystalline CdTe shows greater promises for the development of cost-effective, efficient, and reliable thin film solar cells. Results of numerical analysis using AMPS-1D simulator in exploring the possibility of ultrathin, high efficiency, and stable CdS/CdTe cells are presented. The conventional baseline case structure of CdS/CdTe cell has been explored with reduced CdTe absorber and CdS window layer thickness, where $1 \mu \mathrm{m}$ thin CdTe and $50 \mathrm{~nm}$ CdS layers showed reasonable efficiencies over $15 \%$. The viability of $1 \mu \mathrm{m}$ CdTe absorber layer together with possible back surface field (BSF) layers to reduce minority carrier recombination loss at the back contact in ultra thin CdS/CdTe cells was investigated. Higher bandgap material like ZnTe and low bandgap materials like $\mathrm{Sb}_{2} \mathrm{Te}_{3}$ and $\mathrm{As}_{2} \mathrm{Te}_{3}$ as BSF were inserted to reduce the holes barrier height in the proposed ultra thin CdS/CdTe cells. The proposed structure of $\mathrm{SnO}_{2} / \mathrm{Zn}_{2} \mathrm{SnO}_{4} / \mathrm{CdS} / \mathrm{CdTe} / \mathrm{As}_{2} \mathrm{Te}_{3} / \mathrm{Cu}$ showed the highest conversion efficiency of $18.6 \%(V o c=$ $0.92 \mathrm{~V}, J s c=24.97 \mathrm{~mA} / \mathrm{cm}^{2}$, and $\left.\mathrm{FF}=0.81\right)$. However, other proposed structures such as $\mathrm{SnO}_{2} / \mathrm{Zn}_{2} \mathrm{SnO}_{4} / \mathrm{CdS} / \mathrm{CdTe} / \mathrm{Sb}_{2} \mathrm{Te} 3 / \mathrm{Mo}$ and $\mathrm{SnO}_{2} / \mathrm{Zn}_{2} \mathrm{SnO}_{4} / \mathrm{CdS} / \mathrm{CdTe} / \mathrm{ZnTe} / \mathrm{Al}$ have also shown better stability at higher operating temperatures with acceptable efficiencies. Moreover, it was found that the cells normalized efficiency linearly decreased with the increased operating temperature with relatively lower gradient, which eventually indicates better stability of the proposed ultra thin CdS/CdTe cells.

\section{Introduction}

Over the period of recent decade, cadmium telluride (CdTe) has shown greater promise for efficient, low-cost photovoltaic (PV) solar cells. CdTe-based PV modules are currently entering mass production, but still there are potential scopes remaining for improvement of the cell performance, materials usage, and cell stability. The main technical issues of $\mathrm{CdS} / \mathrm{CdTe}$ cells are related to the lesser material usage and stable back contact. The polycrystalline CdTe has a high absorption coefficient of over $5 \times 10^{5} / \mathrm{cm}$, which means that all the potential photons with energy greater than the bandgap can be absorbed within a very thin $\mathrm{CdTe}$ absorber layer. Moreover, $\mathrm{CdTe}$ has a direct optical bandgap of $1.45 \mathrm{eV}$ which is very close to the optimum bandgap for solar cells. Hence, the lesser thickness required for an absorbing layer can lead to reduced cell material usage and lower cost of fabrication. Undoubtedly one of the main goals of today's PV research is using less semiconductor material by making the cells thinner. Thinning will not only save material usage, but will also lower the production cost, time, and the energy needed to produce the cells. All of these factors will lead to cheaper and affordable solar cells. Therefore, reduction of absorber and window layers 
thickness to the extreme limit are the main focus of this work.

The CdTe thin film solar cells have shown long-term stable performance [1] and high efficiency under AM1.5 illumination for terrestrial usage. From optoelectronic and chemical properties, CdS is the best suited n-type hetero junction partner to CdTe for high efficiency and low cost PV. The maximum theoretical efficiency of CdS/CdTe cell at standard solar spectrum is about $29 \%$. Tyan and PerezAlbuerne reported $\mathrm{CdTe} / \mathrm{CdS}$ thin film solar cells with efficiency of $10 \%$ [2]. Ferekides et al. reported increased in efficiency of $15.8 \%$ [3]. Finally a group of NREL researchers reported a record efficiency of $16.5 \%$ [4]. The $16.5 \%$ efficient champion CdS/CdTe cell used modified cell structure of $\left(\mathrm{CTO} / \mathrm{ZTO} / \mathrm{CdS} / \mathrm{CdTe} / \mathrm{Cu}: \mathrm{HgTe}: \mathrm{Cu}_{x} \mathrm{Te}\right)$ than the conventional structure $\left(\mathrm{SnO}_{2} / \mathrm{CdS} / \mathrm{CdTe} /\right.$ metal $)$ with $10 \mu \mathrm{m}$ of $\mathrm{CdTe}$ and $0.1 \mu \mathrm{m}$ CdS layer fabricated using three different technologies; close-spaced sublimation (CSS) for CdTe layer, chemical bath deposition (CBD) for CdS layer, and magnetron sputtering for all other layers. This champion cell efficiency $(16.5 \%)$ is just a little over half of the theoretical limit (29\%), but it was estimated that practical CdTe devices with 18-19\% efficiencies might be feasible in the near future [5]. This works targets ultra thin $\mathrm{CdS} / \mathrm{CdTe}$ cells with conversion efficiency over $18 \%$ by improving the open circuit voltage ( $V o c)$, the short circuit current density $(J s c)$, and the fill factor $(\mathrm{FF})$.

The performance of CdS/CdTe solar cells can further be increased by reducing $\mathrm{CdS}$ window layer with suitable buffer layer. By incorporating a very thin resistive buffer layer, the CdS layer thickness can be further reduced down to $<50 \mathrm{~nm}$, which significantly improves the blue response, CdS film morphology, and conversion efficiency of the CdS/CdTe devices [6]. It is possible to take advantage of the different properties of two TCOs by forming a buffer layer. Highefficiency CIGS and CdTe devices are generally fabricated with such buffer layer. The CdS window layer is expected to reduce with suitable buffer layer of zinc oxide $(\mathrm{ZnO})$ or zinc stannate $\left(\mathrm{Zn}_{2} \mathrm{SnO}_{4}\right)$.

The formation of a stable, low resistance, nonrectifying contact to p-CdTe thin film is one of the major and critical challenges associated with this technology in the fabrication of efficient and stable solar cells [7]. A stable backcontact that is not significantly rectifying and has a low resistance is essential for good performance and long-term stability of $\mathrm{CdS} / \mathrm{CdTe}$ solar cells. Since CdTe is a p-type semiconductor with a high electron affinity $(\chi=4.5 \mathrm{eV})$ and high band-gap $(1.45 \mathrm{eV})$, a high work function metal is required to make good ohmic contact to p-CdTe. Most metals, however, do not have sufficiently high work functions and therefore form Schottky-barrier contacts to CdTe absorber layer. When the fermi level at the metal/CdTe interface is pinned by surface states, a metal with a reasonably high work function might not make an ohmic contact. The presence of a backcontact barrier can significantly affect the current-voltage (I-V) characteristics of a CdTe cell, primarily by impeding hole transport. This mechanism is one of the causes of the current limiting effect referred to as "rollover". Typically, metals with a high work function $\left(\varphi_{m} \geq 5.9 \mathrm{eV}\right)$ are required to make an ohmic contact to CdTe, but mostly they do not have such high work functions to make good ohmic contacts to p-CdTe, instead tend to form Schottky or blocking barriers [8]. A typical approach to overcome this obstacle is to either reduce the barrier height or moderate its width by heavily doping extra layer of back surface field (BSF) with appropriate material between the CdTe and final metal backcontact. The specific BSF materials chosen to investigate in this work are Zinc Telluride (ZnTe), Antimony Telluride $\left(\mathrm{Sb}_{2} \mathrm{Te}_{3}\right)$, and Arsenic Telluride $\left(\mathrm{As}_{2} \mathrm{Te}_{3}\right)$. The $\mathrm{ZnTe}$, a ptype semiconductor with a direct band gap of $2.26 \mathrm{eV}$ and formation of ohmic contacts to $\mathrm{ZnTe}$ is easier due to its lower work function and the ability to dope it highly p-type. The $\mathrm{Sb}_{2} \mathrm{Te}_{3}$ is a p-type semiconductor with a low optical band gap of $0.3 \mathrm{eV}$ has been used as BSF of CdS/CdTe solar cells. The $\mathrm{Sb}_{2} \mathrm{Te}_{3}$ was proposed by Romeo et al. at the University of Parma (Italy) for CdS/CdTe solar cells [9]. Recently N. Romeo et al. proposed another potential $\mathrm{As}_{2} \mathrm{Te}_{3}$ material as BSF [10]. $\mathrm{As}_{2} \mathrm{Te}_{3}$ is a p-type semiconductor which has a forbidden gap of about $0.6 \mathrm{eV}$ and exhibits resistivity of $10^{-3} \Omega \mathrm{cm}$ at room temperature. It melts at $360^{\circ} \mathrm{C}$ and can evaporate at temperatures higher than $250^{\circ} \mathrm{C}$ in vacuum; they have reported $\mathrm{CdS} / \mathrm{CdTe}$ cell with efficiency of $15.8 \%$ using $\mathrm{As}_{2} \mathrm{Te}_{3}$ material.

Numerical modeling techniques can help in the understanding of solar cells, and should give the additional ideas to vary structures and cell parameters to improve the cell performance. Given the complex nature of CdS/CdTe thin film polycrystalline solar cells, the need for numerical modeling is apparent. Numerical simulations give insight into the mechanism of structures, thereby enabling the design of new structures with better efficiency and performance. There are scopes to increase the conversion efficiency of CdS/CdTe solar cells by improving the Voc, $J s c$, and FF through numerical modeling before involving with fabrication process of the cells. The strategies for improving CdS/CdTe cell output performance have been explored utilizing AMPS 1D (Analysis of Microelectronic and Photonic Structures) [11] simulator, and the obtained results are discussed in the following sections. This analysis has shown that $\mathrm{SnO}_{2} / \mathrm{Zn}_{2} \mathrm{SnO}_{4}$ front contact with $\mathrm{Sb}_{2} \mathrm{Te}_{3} / \mathrm{Mo}$ and $\mathrm{As}_{2} \mathrm{Te}_{3} / \mathrm{Cu}$ as BSF are suitable material system for higher efficiency $(>17.2 \%)$ and stable ultra thin CdS/CdTe cells. However, the performances of the cell with $\mathrm{ZnTe}$ BSF have shown better overall stability than other cells.

\section{Experimental Modeling and Simulation}

Numerical modeling is increasingly being used to obtain insight into the details of the physical operation of solar cells. Modeling and simulation were done using AMPS$1 \mathrm{D}$ simulator to explore the possibilities of thinner CdTe absorber and CdS window layers with high conversion efficiency. The AMPS-1D program has been developed to realistically simulate the electrical characteristics of the thin film heterojunction solar cells. It has been tested for thin film CdTe and CIGS solar cells [19]. The baseline case of CdTe cell [12] was utilized to approximate the highest-efficiency 
TABLE 1: Material parameters used in simulation.

\begin{tabular}{|c|c|c|c|c|c|c|}
\hline Parameter & $\mathrm{n}-\mathrm{SnO}_{2}$ & $\begin{array}{l}\mathrm{n}-\mathrm{ZnO} / \mathrm{n}- \\
\mathrm{Zn}_{2} \mathrm{SnO}_{4} \\
\end{array}$ & $\mathrm{n}-\mathrm{CdS}$ & $\mathrm{p}-\mathrm{CdTe}$ & $\mathrm{ZnTe} / \mathrm{Sb}_{2} \mathrm{Te}_{3} / \mathrm{As}_{2} \mathrm{Te}_{3}$ & $\begin{array}{c}\text { Comments and } \\
\text { references }\end{array}$ \\
\hline Thickness, $W(\mu \mathrm{m})$ & $0.01-0.5$ & $0.02-0.5$ & $0.025-0.2$ & $0.1-6.0$ & $0.01-0.5$ & Variable values \\
\hline Dielectric constant, $\varepsilon / \mathcal{E}_{o}$ & 9.0 & 9.0 & 10.0 & 9.4 & $14 / 55 / 20$ & {$[9,10,12,13]$} \\
\hline Electron mobility, $\mu_{\mathrm{e}}\left(\mathrm{cm}^{2} / \mathrm{Vs}\right)$ & 100 & $100 / 32$ & 100 & 320 & $70 / 1094 / 500$ & {$[10,12,14,15]$} \\
\hline Hole mobility, $\mu_{\mathrm{p}}\left(\mathrm{cm}^{2} / \mathrm{Vs}\right)$ & 25 & $25 / 03$ & 25 & 40 & $50 / 320 / 210$ & {$[10,12,14,15]$} \\
\hline $\begin{array}{l}\text { Electron and hole concentration, } \\
\mathrm{n}, \mathrm{p}\left(\mathrm{cm}^{-3}\right)\end{array}$ & $10^{17}$ & $10^{19}$ & $10^{17}$ & $5 \times 10^{15}$ & $7.5 \times 10^{19}$ & {$[12,16,17]$} \\
\hline Bandgap, $E_{\mathrm{g}}(\mathrm{eV})$ & 3.6 & $3.0 / 3.35$ & 2.42 & 1.45 & $2.25 / 0.3 / 0.6$ & {$[12,16,17]$} \\
\hline $\begin{array}{l}\text { Density of states at conduction } \\
\text { band, } N_{\mathrm{C}}\left(\mathrm{cm}^{-3}\right)\end{array}$ & $2.2 \times 10^{18}$ & $2.0 \times 10^{18}$ & $2.2 \times 10^{18}$ & $8.0 \times 10^{17}$ & $7.5 \times 10^{17}$ & {$[12,16-18]$} \\
\hline $\begin{array}{l}\text { Density of states at valence band, } \\
N_{\mathrm{V}}\left(\mathrm{cm}^{-3}\right)\end{array}$ & $1.8 \times 10^{19}$ & $1.5 \times 10^{19}$ & $1.8 \times 10^{19}$ & $1.8 \times 10^{19}$ & $1.5 \times 10^{19}$ & {$[12,16-18]$} \\
\hline Electron affinity, $\chi(\mathrm{eV})$ & 4.50 & $4.35 / 4.50$ & 4.50 & 4.28 & $3.65 / 4.15 / 4.0$ & {$[12,14-18]$} \\
\hline
\end{tabular}

CdS/CdTe solar cells at that time, and it was modified in this work to explore the possibility of efficient ultra thin cells with suitable BSF. Many researchers have carried out simulations with CdTe-based solar cells, and a list can be found in the references given in the review paper by Burgelman et al. [20]. Figure 1 illustrates the CdTe baseline case structure and modified (Glass/SnO $/ 2 / \mathrm{ZnO} / \mathrm{CdS} / \mathrm{CdTe} / \mathrm{BSF} / \mathrm{Metal}$ ) structure for higher conversion efficiency.

It is clear from Figure 1 that the modified structure has an extra layer $\left(\mathrm{ZnO}\right.$ or $\left.\mathrm{Zn}_{2} \mathrm{SnO}_{4}\right)$ between $\mathrm{SnO}_{2}$ and $\mathrm{CdS}$ layer to achieve thinner CdS window and $\mathrm{SnO}_{2}$ layers for higher performances. Thus, the front contact consists of $\mathrm{SnO}_{2}$ plus a buffer layer of $\mathrm{ZnO}$ or $\mathrm{Zn}_{2} \mathrm{SnO}_{4}$. The doping concentration (up to $10^{14} \mathrm{~cm}^{-3}$ ) used in the baseline case was changed to (up to $10^{15} \mathrm{~cm}^{-3}$ ) for today's achievable values for CdTe material. Proper BSF were inserted to overcome rollover effect, instability at higher operating temperature and to reduce minority carrier recombination loss at the back contact in ultra thin CdS/CdTe cells. Cheaper metals $(\mathrm{Ag} / \mathrm{Al} / \mathrm{Mo})$ were used as final back contact material in the proposed cells for the low cost aspect. The number of parameters that can be varied in a particular solar cell model is larger than 50 [20]. Obviously, a problem with 50 variables is too ambiguous and tedious to solve reliably. It is therefore necessary to minimize the number of variable parameters by fixing many of them at reasonable values. It was a tough challenge to choose the appropriate parameters to be used for the different layers of the cells. Many of them depend on fabrication techniques and deposition methods and can thus vary even between devices fabricated in the same batch. Table 1 shows the significant material parameters used in this modeling, which were selected from various literatures as well as estimations based on theoretical and practically variable values.

A three-layer device model of the baseline case was the starting point of the analysis. Five layers that were emphasized in the modified cells are the front contact $\mathrm{SnO}_{2}$ layer, a buffer layer $\left(\mathrm{ZnO} / \mathrm{Zn}_{2} \mathrm{SnO}_{4}\right)$, n-CdS layer, p-CdTe layer and BSF layer. In this modeling, all the layer thickness were varied: the CdTe layer from $100 \mathrm{~nm}$ up to $6 \mu \mathrm{m}$, CdS window layer from $25 \mathrm{~nm}$ to $200 \mathrm{~nm}, \mathrm{ZnO}$ or $\mathrm{Zn}_{2} \mathrm{SnO}_{4}$ buffer layer from $20 \mathrm{~nm}$ to $500 \mathrm{~nm}$, and BSF layer from $10 \mathrm{~nm}$ to $500 \mathrm{~nm}$ while keeping all other cell parameters at fixed value as shown in Table 1. This modeling has shown the possibility of a highly efficient $18.6 \%\left(V o c=0.92 \mathrm{~V}, J s c=24.97 \mathrm{~mA} / \mathrm{cm}^{2}\right.$ and FF $=0.81) \mathrm{CdS} / \mathrm{CdTe}$ solar cell with $1 \mu \mathrm{m}$ of CdTe, $50 \mathrm{~nm}$ of CdS, $100 \mathrm{~nm}$ of $\mathrm{Zn}_{2} \mathrm{SnO}_{4}$, and $100 \mathrm{~nm}$ of $\mathrm{As}_{2} \mathrm{Te}_{3}$ layers.

\section{Results and Discussion}

3.1. CdTe Absorber Layer and CdS Window Layer Optimization. The conventional CdTe baseline structure [12] $\left(\mathrm{SnO}_{2} / \mathrm{CdS} / \mathrm{CdTe}\right)$ was the starting point of this analysis. The conversion efficiency of $15.0 \%(V o c=0.86 \mathrm{~V}, J s c=$ $24.47 \mathrm{~mA} / \mathrm{cm}^{2}, \mathrm{FF}=0.71$ ) was found from the baseline case structure where CdTe was $4 \mu \mathrm{m}, \mathrm{CdS}$ was $100 \mathrm{~nm}$ and $\mathrm{Ag}$ as the final back contact metal. When the today's achievable CdTe doping concentration $\left(5 \times 10^{16}\right)$ and life time $(1.6 \mathrm{~ns})$ were adopted the cell conversion efficiency increased to $17.4 \%\left(V o c=0.9 \mathrm{~V}, J s c=24.5 \mathrm{~mA} / \mathrm{cm}^{2}, \mathrm{FF}=0.8\right)$. This improvement was achieved mainly from increased $V o c$ and FF due to higher CdTe absorber doping concentration and life time than the baseline case cell. It is noteworthy that in most high efficiency CdS/CdTe solar cells, the CdTe absorber layer is purposely set at $5 \mu \mathrm{m}$ and above to avoid pinhole formation and uniformity limitation. Theoretically the minimum thickness required is approximately $2 \mu \mathrm{m}$ for CdTe layer to absorb $99 \%$ of the incident photons with energy greater than Eg [4]. However, further numerical analysis was done to reduce the thickness of CdTe and CdS layers aiming to conserve the materials usages and cost of cell production. The CdTe absorber thickness was varied from $100 \mathrm{~nm}$ to $6000 \mathrm{~nm}$ to explore thinner CdTe absorber layer using AMPS-1D simulator the simulated results are shown in Figure 2.

It is clear from Figure 2 that all the solar cell output parameters were unaffected around the CdTe thickness of $1 \mu \mathrm{m}$. Further reduction of CdTe thickness from $1 \mu \mathrm{m}$ has shown that $J s c$ decreased slowly but the Voc remained almost unaffected and FF increased below $600 \mathrm{~nm}$. At the lower 


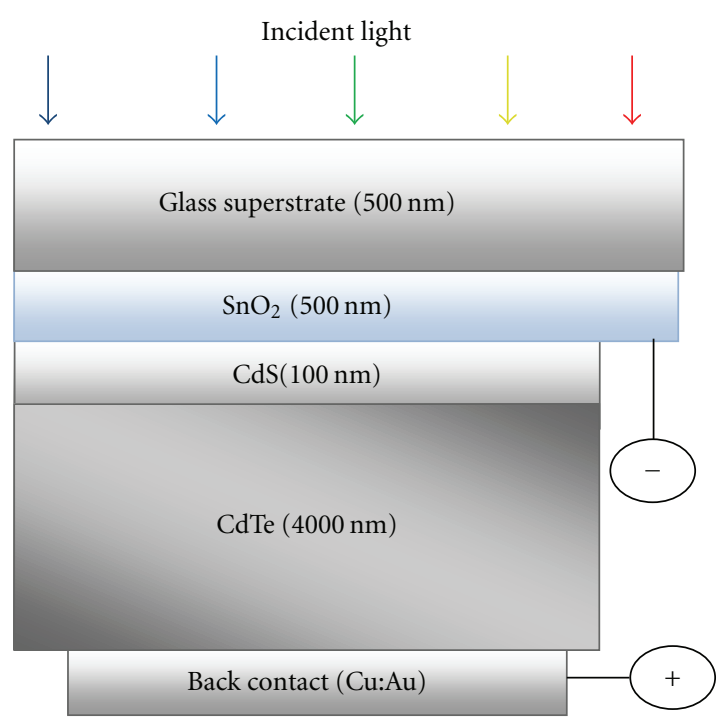

(a)

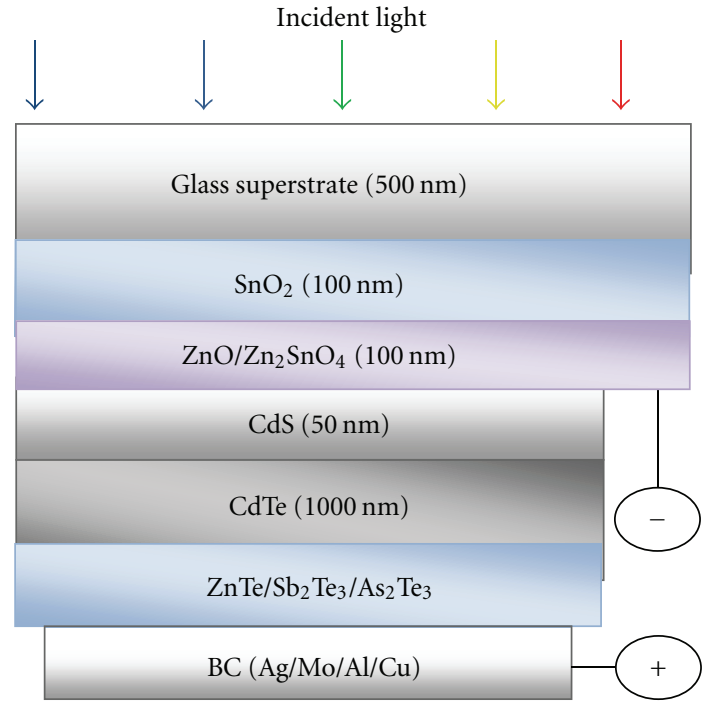

(b)

FIGURE 1: Structures of the CdTe solar cells: (a) conventional baseline case structure and (b) modified structure for higher performance.

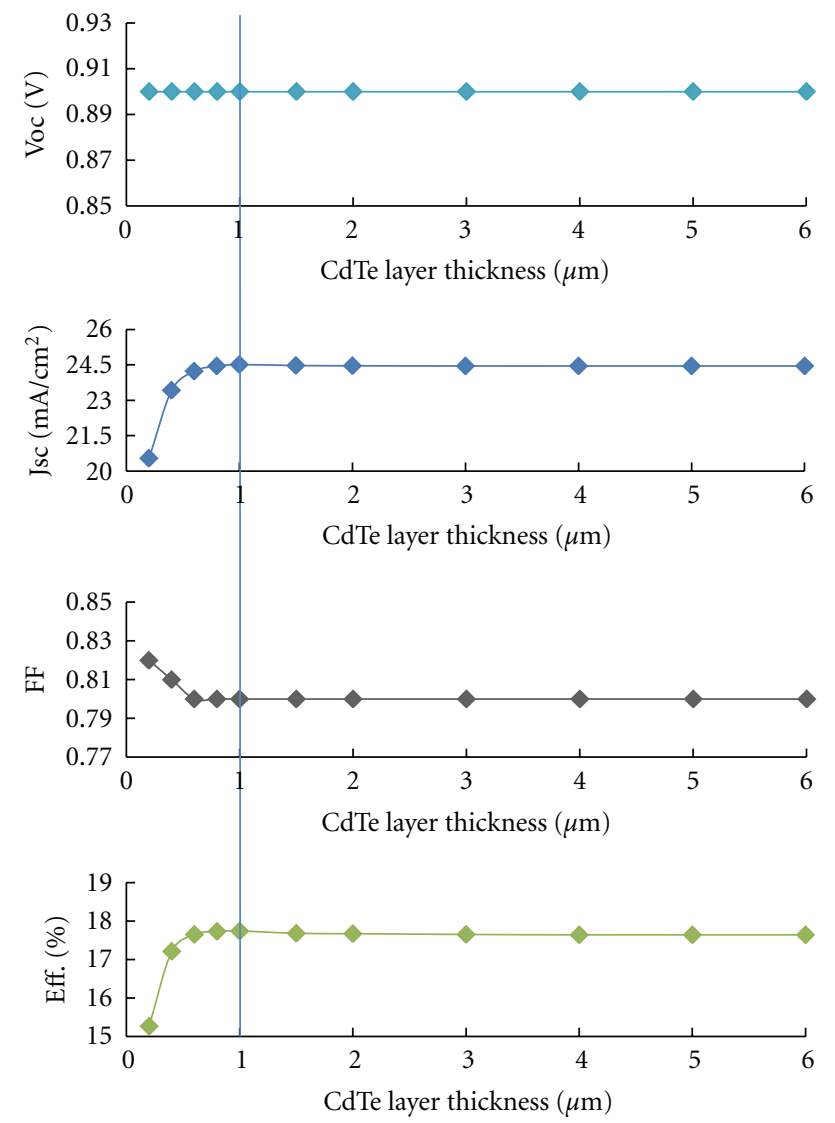

Figure 2: Effect of CdTe film thickness on cell parameters.

value of CdTe thickness $(<0.5 \mu \mathrm{m})$ the $J s c$ decreased sharply because the minority carrier diffusion length is critically shorter but FF showed a little increased value due to

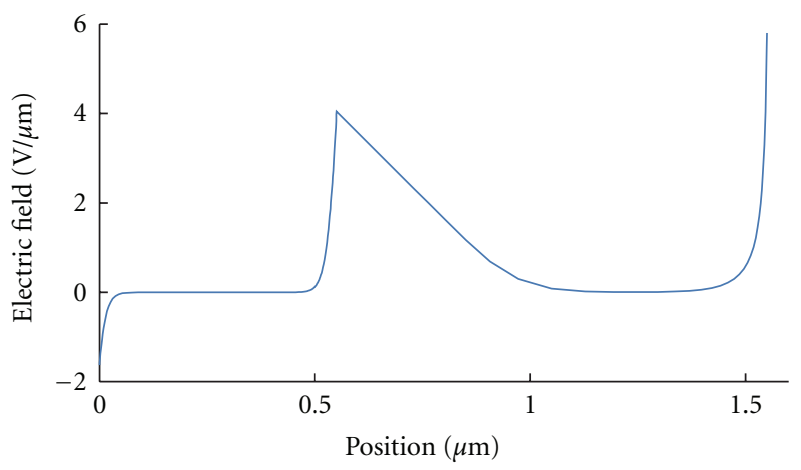

FIGURE 3: Electric field distribution in CdS/CdTe thin film solar cell.

the reduction of bulk resistance for CdTe material. As a combined effect, efficiency decreased with reduced $\mathrm{CdTe}$ thickness below $1 \mu \mathrm{m}$, which indicated that selection of $1 \mu \mathrm{m}$ CdTe absorber is safe.

It can be seen from the electric field distribution of Figure 3 for the $1 \mu \mathrm{m}$ thick CdTe cell that the electric field diminishes before $1 \mu \mathrm{m}$ of CdTe thickness. The charge depletion extends approximately 0.6 microns into the $\mathrm{CdTe}$ layer. If the thickness of the CdTe layer is restricted to smaller values $(<0.6 \mu \mathrm{m})$, then the layer is said to be "fully depleted". While collection in a fully depleted device is usually good due to the field strength at all positions but built-in potential and hence device voltage tend to be reduced. The $1 \mu \mathrm{m}$ thick CdTe cell shows acceptable conversion efficiency of $17.4 \%$ ( $V o c=$ $\left.0.90 \mathrm{~V}, J s c=24.5 \mathrm{~mA} / \mathrm{cm}^{2}, \mathrm{FF}=0.8\right)$. These results are in good agreements with related published works for CdTe cells $[13,14]$.

However, there are possibility of increasing $J_{s c}$ as well as the cell conversion efficiency if the CdS window layer thickness $(100 \mathrm{~nm})$ can be reduced further with insertion of 


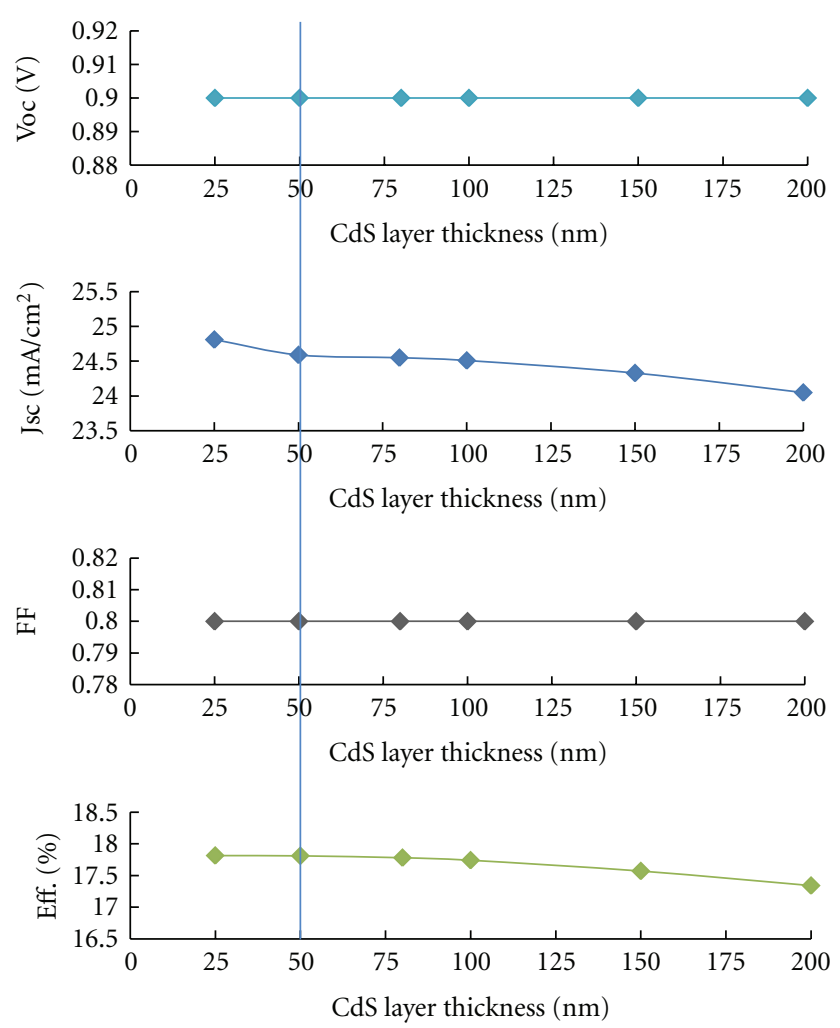

FIGURE 4: Effect of CdS window layer thickness on cell parameters.

a suitable buffer layer between $\mathrm{SnO}_{2}$ and CdS layer. Moreover, the buffer layer might constitute a barrier against diffusion of unwanted species from the substrate and $\mathrm{SnO}_{2}$ layer to CdS.

When the CdS film thickness has been reduced to explore thinner CdS layer, the absorption loss in the blue region due to thick CdS layer reduces, which improves mainly Jsc and cell conversion efficiency. Figure 4 shows the effects in details of CdS layer variation from $25 \mathrm{~nm}$ to $200 \mathrm{~nm}$ on the cell output parameters from AMPS 1D simulation, when utilizing all the parameters of Table 1 and $1 \mu \mathrm{m} \mathrm{CdTe}$ absorber layer.

Figure 4 shows that $J s c$ improved with reduced CdS layer but $V o c$ and FF are not so much affected. Thus, from the combined effect the conversion efficiency increases with CdS layer thickness reduction. The spectral response (SR) of CdS layer thickness variation from $25 \mathrm{~nm}$ to $200 \mathrm{~nm}$ is shown in Figure 5 from where the improvement of $J s c$ will be visibly noticeable.

It is evident that when the operating wavelength is below $510 \mathrm{~nm}$ the quantum efficiency (QE) was significantly affected with increasing CdS layer thickness. This affected mainly $J s c$ and finally the conversion efficiency of the cell. This result is in good agreement with other published works [14]. However, to date; it is impractical to fabricate cells with CdS film thickness below $50 \mathrm{~nm}$. Considering the fabrication constraint, the CdS film thickness of $50 \mathrm{~nm}$ was selected with conversion efficiency of $17.8 \%(V o c=0.9 \mathrm{~V}$, $\left.J s c=24.6 \mathrm{~mA} / \mathrm{cm}^{2}, \mathrm{FF}=0.8\right)$. Thus, it is very clear that

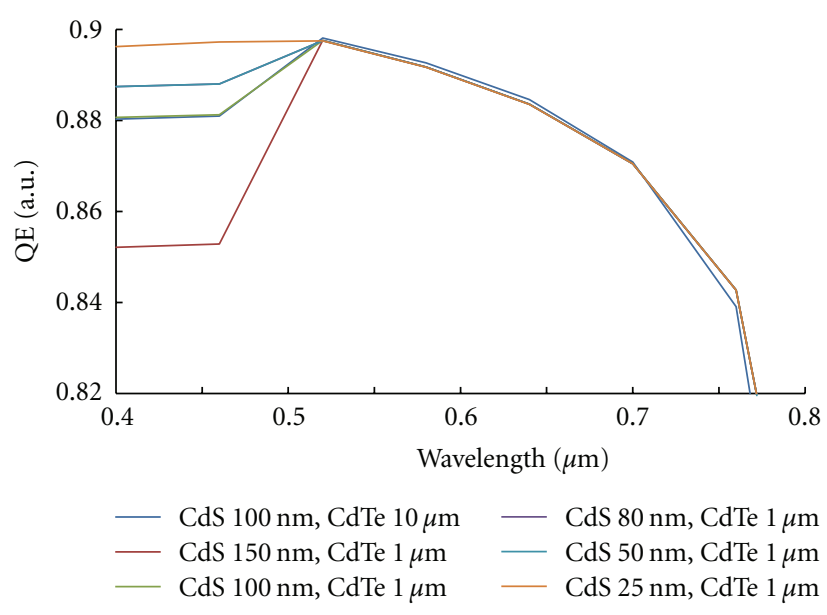

Figure 5: Effect of CdS window layer thickness on the spectral response (quantum efficiency).

the improved cell performance has been achieved mainly due to the improvement of $J s c$.

3.2. Insertion of $\mathrm{ZnO} / \mathrm{Zn}_{2} \mathrm{SnO}_{4}$ Buffer Layer. The CdS layer was reduced to $50 \mathrm{~nm}$, for such a thin CdS window layer it was necessary to insert front contact buffer layer for further improvement of the cell performance. This $50 \mathrm{~nm}$ thick CdS layer might be attributed to the forward leakage current to front contact through pinholes in the CdS layer. In order to prevent this unwanted forward leakage current a high resistive buffer layer of suitable material ( $\mathrm{ZnO}$ or $\mathrm{Zn}_{2} \mathrm{SnO}_{4}$ ) was inserted between $\mathrm{SnO}_{2}$ and $\mathrm{CdS}$ window layer. Now the front contact of the proposed cells consist of a highly conducting layer of $\mathrm{SnO}_{2}$ material as TCO for low resistance due to contact and lateral current collection and a much thinner high resistivity layer of a suitable buffer material $\left(\mathrm{ZnO}\right.$ or $\left.\mathrm{Zn}_{2} \mathrm{SnO}_{4}\right)$. Further numerical analysis was done using AMPS-1D to investigate the cells performances with proposed buffer layers $\left(\mathrm{ZnO}\right.$ or $\left.\mathrm{Zn}_{2} \mathrm{SnO}_{4}\right)$. The buffer layers were inserted in the designed $\mathrm{CdTe}$ cell with $1 \mu \mathrm{m} \mathrm{CdTe}$, $50 \mathrm{~nm} \mathrm{CdS}, 100 \mathrm{~nm} \mathrm{SnO}_{2}$ layers, and all other parameter as in Table 1. Moreover, I-V characteristics obtained from AMPS1D simulation with buffer layers are shown in Figure 6.

$\mathrm{ZnO}$ insertion has shown almost the same result with $\mathrm{Zn}_{2} \mathrm{SnO}_{4}$ insertion as the material properties are very close to each other. With the insertion of $\mathrm{ZnO}$ and $\mathrm{Zn}_{2} \mathrm{SnO}_{4}$ the $\mathrm{I}-\mathrm{V}$ curve had shown higher shunt and series resistances. Higher shunt resistance is desired for the better performance of cells, but higher series resistance is undesirable which might reduce the FF. The cell output characteristics are independent of the $\mathrm{ZnO} / \mathrm{Zn}_{2} \mathrm{SnO}_{4}$ thickness from $20 \mathrm{~nm}$ up to $500 \mathrm{~nm}$. Moreover, it was observed that the SR of the cells were unaffected by the $\mathrm{ZnO} / \mathrm{Zn}_{2} \mathrm{SnO}_{4}$ thickness variation from $20 \mathrm{~nm}$ to $500 \mathrm{~nm}$, meaning that a very thin buffer layer is adequate for the purpose. Considering the reality in fabrication, the $\mathrm{ZnO} / \mathrm{Zn}_{2} \mathrm{SnO}_{4}$ buffer layer thickness was selected $100 \mathrm{~nm}$ with maximum cell conversion efficiency of $17.8 \%$. It is noticeable here that with the insertion of buffer layer the efficiency of the cells did not improve but 


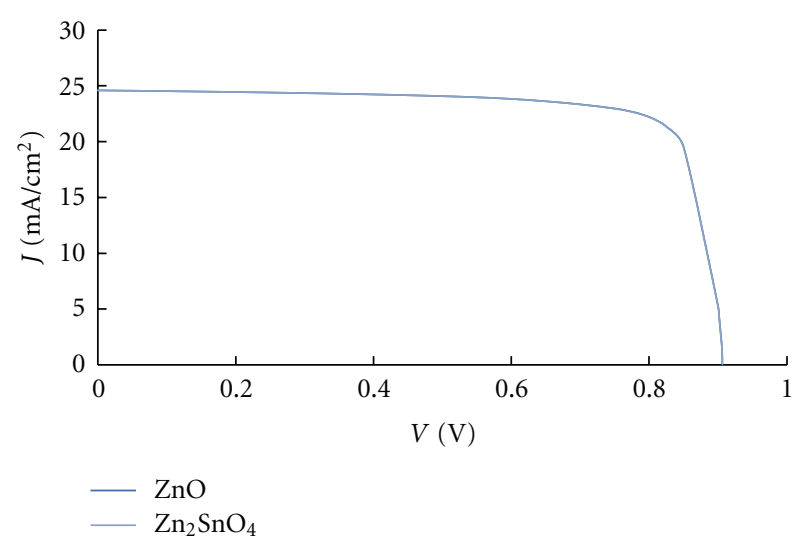

Figure 6: Effect of $\mathrm{ZnO}$ and $\mathrm{Zn}_{2} \mathrm{SnO}_{4}$ on the current-voltage characteristics of the solar cell.

the $\mathrm{SnO}_{2}$ layer was reduced to $100 \mathrm{~nm}$ from $500 \mathrm{~nm}$, which means that reduced material use can reduce the production cost. However, until now the proposed cells are with Ag as the final back contact material. There are scopes for further improvement of cell's performance with BSF layer and with other suitable back contact metals.

3.3. Insertion of BSF and Cells Stability. One of the major differences of thin cells compared to the thicker ones is that the absorber/back contact interface is now located closer to the p-CdTe and n-CdS junction, and the choice of the backcontact material therefore has a high impact on the cell performance. A stable backcontact that is not significantly rectifying is essential for good performance and long-term stability of CdS/CdTe cells. The formation of a low resistance, low barrier backcontact is one of the most challenging aspects for high performance CdTe-based solar cells.

Further numerical analysis has been done with the proposed ultra thin cell $\left(\mathrm{SnO}_{2} / \mathrm{Zn}_{2} \mathrm{SnO}_{4} / \mathrm{CdS} / \mathrm{CdTe} / \mathrm{Ag}\right)$ aiming to explore the performances with three different BSF materials. The cells with $1 \mu \mathrm{m} \mathrm{CdTe,} 50 \mathrm{~nm} \mathrm{CdS,} 100 \mathrm{~nm}$ $\mathrm{SnO}_{2}$, and $100 \mathrm{~nm}$ BSF layers were simulated using AMPS$1 \mathrm{D}$; the obtained results are summarized in Table 2.

It is evident from Table 2 that the proposed best cell without any BSF layer shows conversion efficiency of $17.8 \%$, which is a high value for CdS/CdTe cells. When ZnTe is inserted as a BSF the conversion efficiency drops as the FF was strongly affected but the $J s c$ improved a bit due to reduced minority carrier recombination loss at the back contact. The reduction in FF might be attributed to the barrier developed for holes in the valance band and $J s c$ improved due to electrons reflected back from the conduction band, which will be clearer from the band diagram of the cells (Figure 7). When $\mathrm{Sb}_{2} \mathrm{Te}_{3}$ was inserted as BSF layer the FF and conversion efficiency improved better than that of ZnTe BSF because there is no barrier for holes at the valance band. The $\mathrm{As}_{2} \mathrm{Te}_{3}$ BSF produced best cell performances and highest conversion efficiency of $18.6 \%$. The improvement in efficiency of this cell came from the improvement of all the cell output parameters like FF, Voc, and $J s c$.

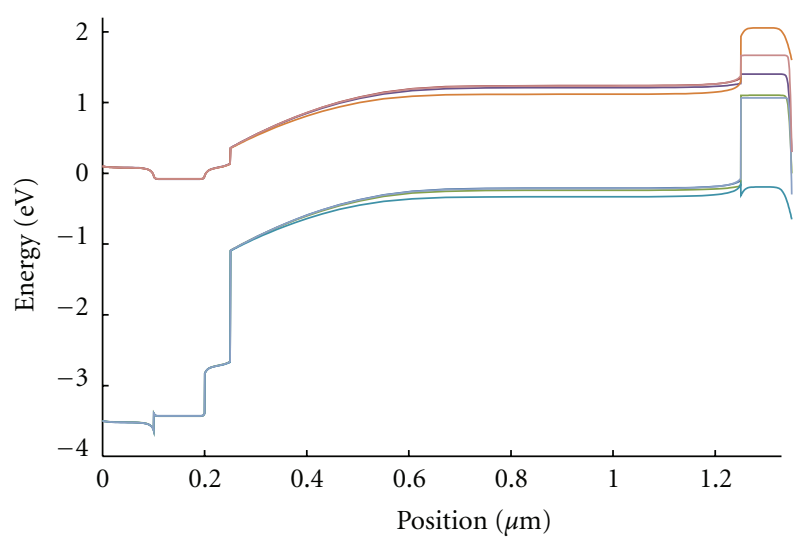

$\mathrm{SnO}_{2} / \mathrm{Zn}_{2} \mathrm{SnO}_{4} / \mathrm{CdS} / \mathrm{CdTe} \mathrm{VB}$
$\mathrm{SnO}_{2} / \mathrm{Zn}_{2} \mathrm{SnO}_{4} / \mathrm{CdS} / \mathrm{CdTe} \mathrm{CB}$
$\mathrm{SnO}_{2} / \mathrm{Zn}_{2} \mathrm{SnO}_{4} / \mathrm{CdS} / \mathrm{CdTe} / \mathrm{Sb}_{2} \mathrm{Te}_{3} \mathrm{VB}$
$\mathrm{SnO}_{2} / \mathrm{Zn}_{2} \mathrm{SnO}_{4} / \mathrm{CdS} / \mathrm{CdTe} / \mathrm{Sb}_{2} \mathrm{Te}_{3} \mathrm{CB}$
$-\mathrm{SnO}_{2} / \mathrm{Zn}_{2} \mathrm{SnO}_{4} / \mathrm{CdS} / \mathrm{CdTe} / \mathrm{ZnTe} \mathrm{VB}$
$\mathrm{SnO}_{2} / \mathrm{Zn}_{2} \mathrm{SnO}_{4} / \mathrm{CdS} / \mathrm{CdTe} / \mathrm{ZnTe} \mathrm{CB}$
$\mathrm{SnO}_{2} / \mathrm{Zn}_{2} \mathrm{SnO}_{4} / \mathrm{CdS} / \mathrm{CdTe} / \mathrm{As}_{2} \mathrm{Te}_{3} \mathrm{VB}$
$\mathrm{SnO}_{2} / \mathrm{Zn}_{2} \mathrm{SnO}_{4} / \mathrm{CdS} / \mathrm{CdTe} / \mathrm{As}_{2} \mathrm{Te}_{3} \mathrm{CB}$

FIGURE 7: Band diagram of the proposed cells.

Figure 7 shows the band diagram of the proposed cells without BSF, with $\mathrm{ZnTe} / \mathrm{Al} \mathrm{BSF}, \mathrm{Sb}_{2} \mathrm{Te}_{3} / \mathrm{Mo} \mathrm{BSF}$, and $\mathrm{As}_{2} \mathrm{Te}_{3} / \mathrm{Al} \mathrm{BSF}$ at zero voltage biasing. The front contacts of the cells are the same $\left(\mathrm{SnO}_{2} / \mathrm{Zn}_{2} \mathrm{SnO}_{4} / \mathrm{CdS}\right)$ with a band discontinuity of $0.22 \mathrm{eV}$ at CdS-CdTe junction. Without any BSF layer it was found that there is a rectifying back contact with p-CdTe and Ag material which might be responsible for "rollover" of this cell. Smoother collections of holes are anticipated as there is no barrier in the conduction band for all the proposed cells except the cell with ZnTe BSF.

It is clear from the figure that the $\mathrm{ZnTe}$ has shown a barrier at the valance band of CdTe and ZnTe interface which might be responsible for its lower FF and conversion efficiency. All the BSF will effectively reflect back the electrons from the conduction band interface of CdTe-BSF towards the front contact as there is adequate barrier height in the conduction band of all the cells with BSF. For $\mathrm{Sb}_{2} \mathrm{Te}_{3}$ the barrier height is $0.2 \mathrm{eV}$, for $\mathrm{As}_{2} \mathrm{Te}_{3}$, the barrier height is $0.45 \mathrm{eV}$, and for $\mathrm{ZnTe}$ barrier height is $0.8 \mathrm{eV}$. Due to these barrier heights, cells with BSF have shown higher Jsc. It seems that $0.2 \mathrm{eV}$ BSF is enough for the purpose of reflecting back the electrons towards front contact. Moreover, $J-V$ characteristics of all the proposed cells are shown in Figure 8.

As can be seen in the figure, the structure with BSF shows higher $J s c$ than the cell without BSF, while the cell with $\mathrm{ZnTe} / \mathrm{Al}$ shows higher $J s c$ but poor FF due to the barrier for holes in the valance band and higher series resistance added by the bulk resistance of the higher bandgap and lower dielectric property of the $\mathrm{ZnTe}$ material. The $\mathrm{Sb}_{2} \mathrm{Te}_{3} / \mathrm{Mo}$ shows moderate cell output parameters. In this analysis $\mathrm{As}_{2} \mathrm{Te}_{3} / \mathrm{Cu}$ has shown improved performances better than $\mathrm{Sb}_{2} \mathrm{Te}_{3} / \mathrm{Mo}$ and $\mathrm{ZnTe} / \mathrm{Al}$. Before any final conclusion on the BSF results, there is need to investigate the stability of the cells at higher operating temperatures. 
TABLE 2: Output parameters of different cells with BSF.

\begin{tabular}{|c|c|c|c|c|}
\hline Different cell structures & $\operatorname{Voc}(\mathrm{V})$ & $J s c\left(\mathrm{~mA} / \mathrm{cm}^{2}\right)$ & $\mathrm{FF}$ & Eff. (\%) \\
\hline Glass $/ \mathrm{SnO}_{2} / \mathrm{Zn}_{2} \mathrm{SnO}_{4} / \mathrm{CdS} / \mathrm{CdTe} / \mathrm{Ag}$ & 0.90 & 24.60 & 0.80 & 17.8 \\
\hline Glass $/ \mathrm{SnO}_{2} / \mathrm{Zn}_{2} \mathrm{SnO}_{4} / \mathrm{CdS} / \mathrm{CdTe} / \mathrm{ZnTe} / \mathrm{Al}$ & 0.90 & 24.92 & 0.70 & 15.8 \\
\hline Glass $/ \mathrm{SnO}_{2} / \mathrm{Zn}_{2} \mathrm{SnO}_{4} / \mathrm{CdS} / \mathrm{CdTe} / \mathrm{Sb}_{2} \mathrm{Te}_{3} / \mathrm{Mo}$ & 0.91 & 24.94 & 0.75 & 17.2 \\
\hline Glass $/ \mathrm{SnO}_{2} / \mathrm{Zn}_{2} \mathrm{SnO}_{4} / \mathrm{CdS} / \mathrm{CdTe} / \mathrm{As}_{2} \mathrm{Te}_{3} / \mathrm{Cu}$ & 0.92 & 24.97 & 0.81 & 18.6 \\
\hline
\end{tabular}

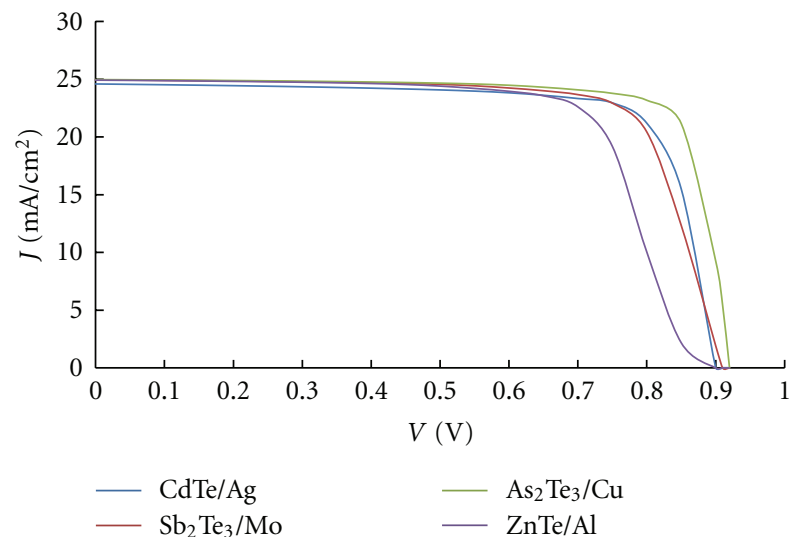

Figure 8: $J-V$ characteristics of the proposed cells.

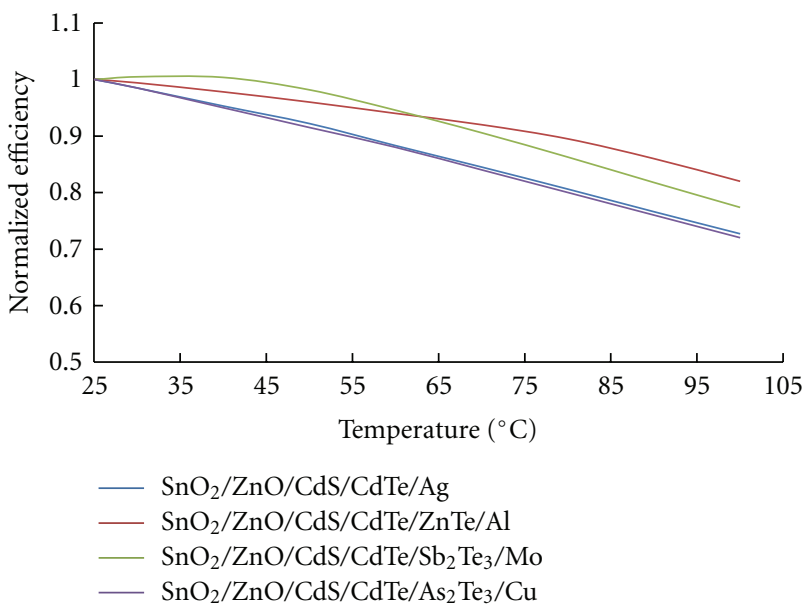

FIGURE 9: Effects of operating temperature on the proposed cell performance.

Operating temperature plays a very important role for the cell performance in the field. It is quite expected that at higher operating temperature, parameters such as the electron and hole mobility, carrier concentrations, density of states, and band gaps of the materials are affected, as also found in this analysis. An investigation was conducted utilizing AMPS-1D at operating temperature ranged from $25^{\circ} \mathrm{C}$ to $100^{\circ} \mathrm{C}$ for the proposed cells. The results obtained from AMPS-1D simulation are shown in Figure 9.

In the figure, it is evident that without BSF layer the cell conversion efficiency linearly decreased with the increase of operating temperature with a temperature coefficient (TC) of $-0.4 \% /{ }^{\circ} \mathrm{C}$, which is in good agreement with related works $[15,16]$. Cells with $\mathrm{Sb}_{2} \mathrm{Te}_{3} / \mathrm{Mo}$ gives better stability as its efficiency remains almost unchanged in the operating temperature range from $25^{\circ} \mathrm{C}$ to $45^{\circ} \mathrm{C}$, and then it decreases with a $\mathrm{TC}$ of $-0.4 \% /{ }^{\circ} \mathrm{C}$, same as that obtained in cell without BSF. The stability of cell with $\mathrm{As}_{2} \mathrm{Te}_{3} / \mathrm{Cu}$ showed the same stability of the cell without BSF. Thus, the $\mathrm{As}_{2} \mathrm{Te}_{3}$ has no effects on the cell stability at higher operating temperature. The cell with $\mathrm{ZnTe}$ showed better stability with $\mathrm{TC}$ of $-0.3 \% /{ }^{\circ} \mathrm{C}$. However, the performances of the cells with $\mathrm{ZnTe}$ have shown better overall stability than other proposed cells.

\section{Conclusion}

A highly efficient $18.6 \%\left(V o c=0.92 \mathrm{~V}, J s c=24.97 \mathrm{~mA} / \mathrm{cm}^{2}\right.$ and $\mathrm{FF}=0.81)$ ultra thin $\mathrm{CdS} / \mathrm{CdTe}$ solar cell with $1 \mu \mathrm{m}$ of CdTe, $50 \mathrm{~nm}$ of CdS, $100 \mathrm{~nm} \mathrm{SnO}, 100 \mathrm{~nm}$ of $\mathrm{Zn}_{2} \mathrm{SnO}_{4}$, and $100 \mathrm{~nm}$ of $\mathrm{As}_{2} \mathrm{Te}_{3}$ has been obtained. The higher doping concentration and life time of CdTe absorber lead to higher cell performance. It was found from the CdTe baseline case cell $\left(\mathrm{SnO}_{2} / \mathrm{CdS} / \mathrm{CdTe}\right)$ that $1 \mu \mathrm{m}$ thick $\mathrm{CdTe}$ absorber layer is possible with acceptable range of efficiency. Moreover, it was found that the reduced CdS layer thickness improves the spectral response of the cell at the blue region with suitable buffer layer of $\mathrm{ZnO} / \mathrm{Zn}_{2} \mathrm{SnO}_{4}$. The $\mathrm{Zn}_{2} \mathrm{Sn}_{\mathrm{O}}$ buffer layer insertion showed almost the same results with $\mathrm{ZnO}$ insertion. It has also been found that $\mathrm{SnO}_{2} / \mathrm{Zn}_{2} \mathrm{SnO}_{4}$ front contacts with $\mathrm{Sb}_{2} \mathrm{Te}_{3} / \mathrm{Mo}$ and $\mathrm{As}_{2} \mathrm{Te}_{3} / \mathrm{Cu}$ as $\mathrm{BSF}$ are suitable contacts for higher efficiency $(>17.2 \%)$ and stable ultra thin CdS/CdTe cells. Moreover, the simulation result of cell operating temperature has shown the stability, to some extent, of the proposed cells at higher operating temperatures. Structures with ZnTe BSF have showed better stability in general, and in particular the structure $\mathrm{SnO}_{2} / \mathrm{Zn}_{2} \mathrm{SnO}_{4} / \mathrm{CdS} / \mathrm{CdTe} / \mathrm{ZnTe} / \mathrm{Al}$ achieved the best stability with a linear thermal coefficient of $-0.3 \% /{ }^{\circ} \mathrm{C}$. From the consideration of both efficiency and stability, structures with $\mathrm{As}_{2} \mathrm{Te}_{3} / \mathrm{Cu}\left(\mathrm{SnO}_{2} / \mathrm{Zn}_{2} \mathrm{SnO}_{4} / \mathrm{CdS} / \mathrm{CdTe} / \mathrm{As}_{2} \mathrm{Te}_{3} / \mathrm{Cu}\right)$ proved to be comparable to other reported cells, and the proposed cells can be investigated using standard fabrication techniques of $\mathrm{CdS} / \mathrm{CdTe}$ cells.

\section{Acknowledgments}

This work has been supported by the Department of Electrical, Electronic and System Engineering and Solar Energy Research Institute (SERI), UKM, Malaysia through the research Grant no. UKM-GUP-BTT-07-29-026. 


\section{References}

[1] D. L. Bätzner, A. Romeo, H. Zogg, R. Wendt, and A. N. Tiwari, "Development of efficient and stable back contacts on CdTe/CdS solar cells," Thin Solid Films, vol. 387, no. 1-2, pp. 151-154, 2001.

[2] Y. S. Tyan and E. A. Perez-Albuerne, "Efficient thin-film CdS/CdTe solar cells," in Proceedings of the 16th IEEE Photovoltaic Specialists Conference, pp. 794-800, New York, NY, USA, 1982.

[3] C. Ferekides, J. Britt, Y. Ma, and L. Killian, "High efficiency CdTe solar cells by close spaced sublimation," in Proceedings of the 23rd IEEE Photovoltaic Specialists Conference, pp. 389-393, New York, NY, USA, May 1993.

[4] X. Wu, "High-efficiency polycrystalline CdTe thin-film solar cells," Solar Energy, vol. 77, no. 6, pp. 803-814, 2004.

[5] S. H. Demtsu and J. R. Sites, in Proceedings of the 30th IEEE Photovoltaic Specialist Conference, pp. 744-747, January 2005.

[6] A. Morales-Acevedo, "Thin film CdS/CdTe solar cells: research perspectives," Solar Energy, vol. 80, no. 6, pp. 675-681, 2006.

[7] N. Romeo, A. Bosio, R. Tedeschi, A. Romeo, and V. Canevari, "Highly efficient and stable CdTe/CdS thin film solar cell," Solar Energy Materials \& Solar Cells, vol. 58, no. 2, pp. 209218, 1999.

[8] L. D. Partain, Solar Cells and Their Applications, Wiley, New York, NY, USA, 1995.

[9] N. Romeo, A. Bosio, R. Tedeschi, and V. Canevari, "Back contacts to CSS CdS/CdTe solar cells and stability of performances," Thin Solid Films, vol. 361, pp. 327-329, 2000.

[10] N. Romeo, A. Bosio, and A. Romeo, "An innovative process suitable to produce high-efficiency CdTe/CdS thin-film modules," Solar Energy Materials \& Solar Cells, vol. 94, no. 1, pp. $2-7,2010$.

[11] S. J. Fonash et al., http://www.ampsmodeling.org/ .

[12] M. Gloeckler, A. L. Fahrenbruch, and J. R. Sites, "Numerical modeling of CIGS and CdTe solar cells: setting the baseline," in Proceddings of the 3rd World Conference on Photovoltaic Energy Conversion, pp. 491-494, May 2003.

[13] M. A. M. Bhuiyan, N. Amin, and K. Sopian, "Effects of absorber and window layer thickness on CdS/CdTe thin film solar cells from numerical analysis by SCAPS 1D," in Regional Student Conference on Research and Development (SCOReD '08), p. 210, IEEE, UTM Malaysia, November 2008.

[14] M. A. Matin, N. Amin, A. Zaharim, and K. Sopian, "Ultra thin high efficiency CdS/CdTe thin film solar cells from numerical analysis," in Proceedings of the 8th WSEAS International Conference on Nonlinear Analysis, Nonlinear Systems and Chaos (NOLASC '09), pp. 338-344, La Laguna, Spain, July 2009.

[15] M. A. Matin, N. Amin, A. Islam, K. Sopian, and K.-K. Chong, "Effect of structural variation in cadmium telluride thin film solar cells from numerical analysis," in Proceedings of the 24th European Photovoltaic Solar Energy Conference, pp. 3072-3076, Hamburg, Germany, September 2009.

[16] M. A. Matin, M. Mannir Aliyu, A. H. Quadery, and N. Amin, "Prospects of novel front and back contacts for high efficiency cadmium telluride thin film solar cells from numerical analysis," Solar Energy Materials \& Solar Cells, vol. 94, pp. 1496-1500, 2010.

[17] P. Mahawela, G. Sivaraman, S. Jeedigunta et al., "II-VI compounds as the top absorbers in tandem solar cell structures," Materials Science and Engineering B, vol. 116, no. 3, pp. 283291, 2005.

[18] M. A. Matin, N. Amin, A. Zaharim, and K. Sopian, "A study towards the possibility of ultra thin Cds/CdTe high efficiency solar cells from numerical analysis," WSEAS Transactions on Environment and Development, vol. 6, no. 8, pp. 571-580, 2010.

[19] S. Degrave, M. Burgelman, and P. Nollet, "Modelling of polycrystalline thin film solar cells: new features in scaps version 2.3," in Proceddings of the 3rd World Conference on Photovoltaic Energy Conversion, pp. 487-490, May 2003.

[20] M. Burgelman, J. Verschraegen, S. Degrave, and P. Nollet, "Modeling thin-film PV devices," Progress in Photovoltaics: Research and Applications, vol. 12, no. 2-3, pp. 143-153, 2004. 


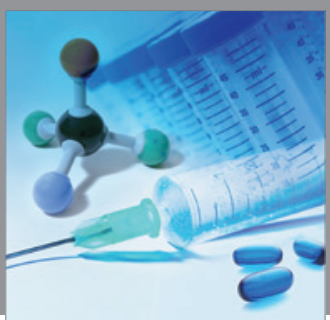

International Journal of

Medicinal Chemistry

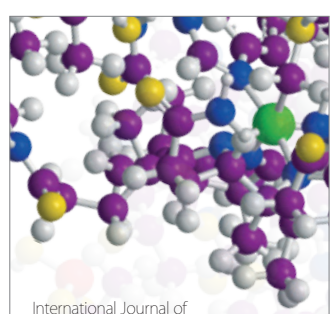

Carbohydrate Chemistry

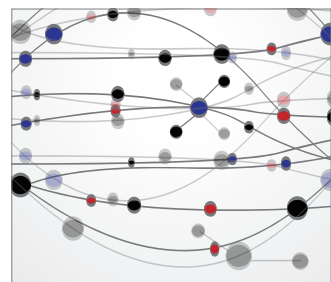

The Scientific World Journal
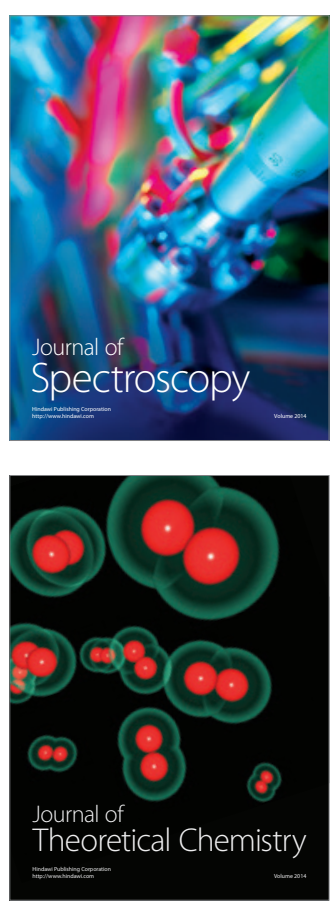
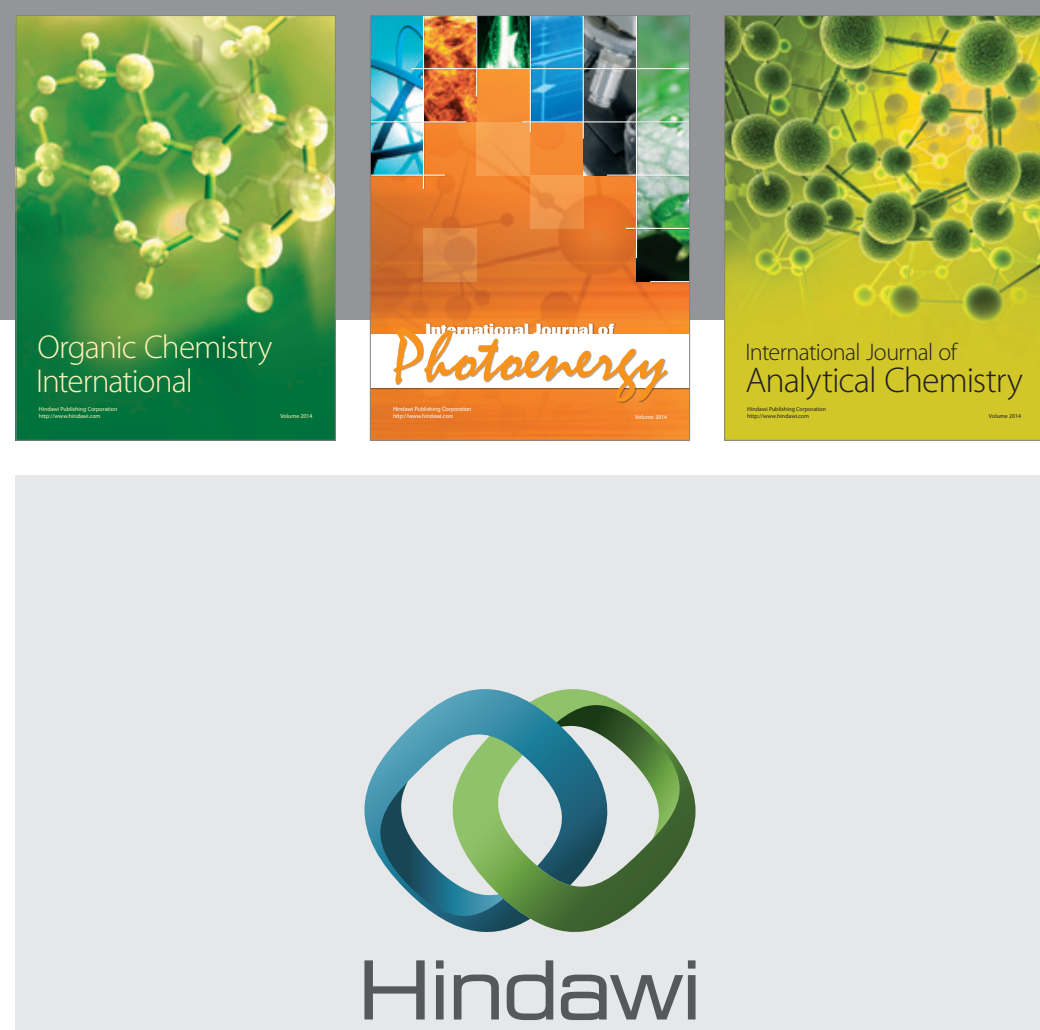

Submit your manuscripts at

http://www.hindawi.com
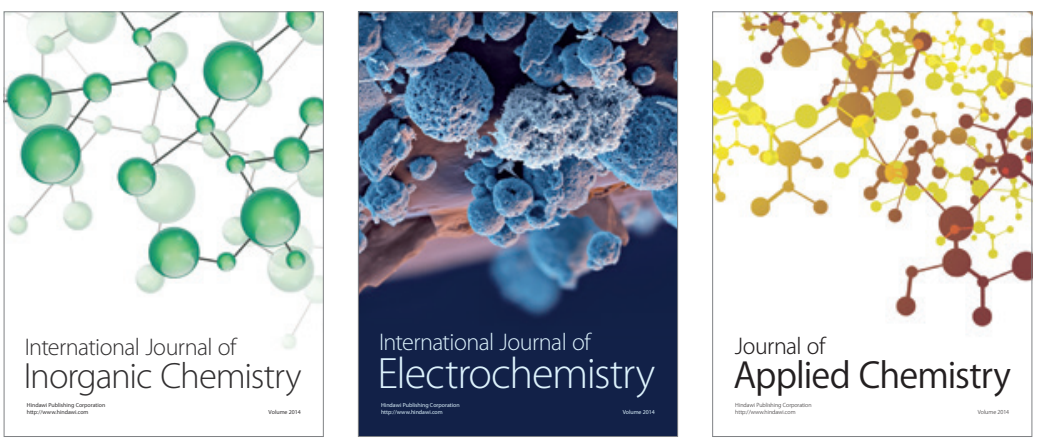

Journal of

Applied Chemistry
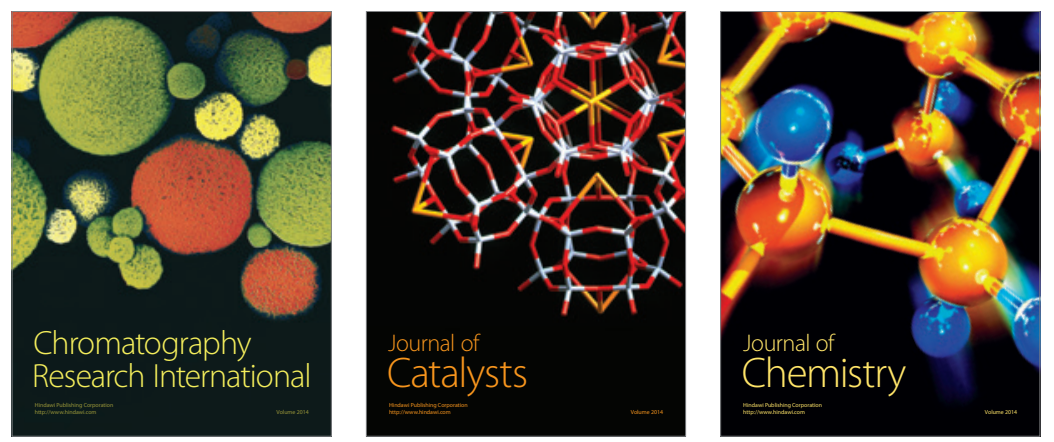
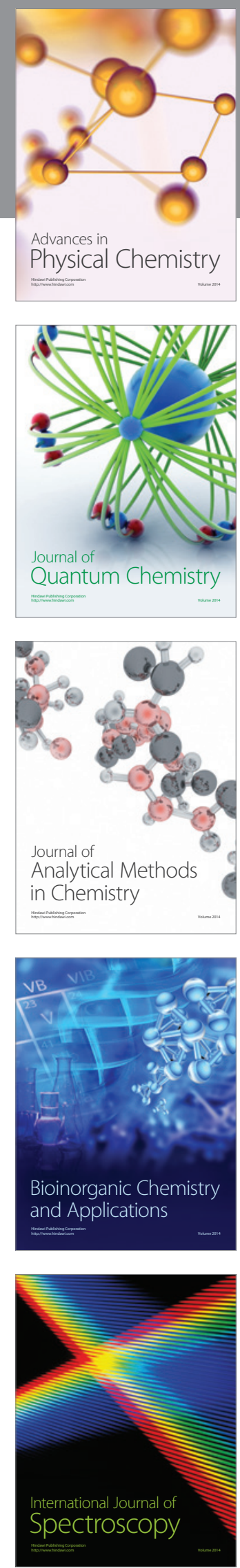